\title{
The Kosovo War In The British Parliament Talks In 1999
}

\author{
Simon Lufi \\ Marsel Nilaj \\ Department of History, Faculty of Social Sciences, \\ University of Shkodra "Luigj Gurakuqi” Albania
}

doi: 10.19044/esj.2016.v12n17p24 URL:http://dx.doi.org/10.19044/esj.2016.v12n17p24

\begin{abstract}
The Kosovo War in the 1990s was one among a series of wars in the former Yugoslav federation. It was the final war that ended the dissolution which had started with Slovenia from1990 to 1991, Croatia and Bosnia Herzegovina from 1992 to 1995 and the Kosovo War from 1998 to 1999. However, the Kosovo war happened during a different situation and period. It was at a time and in a position to cause the domino effect in the Balkans and an outbreak of wars in a large part of the Balkans. This fight could include Albania and Macedonia as nations with an ethnic Albanian population. It could also have a religious or cultural impact that threatened to involve other states such as Bosnia and Turkey on the one hand and Greece on the other. The interest of major countries in Europe, as well as the world, was focused on this war. A country among them was the UK. As one of the founding states of the European Union, United Nations, and NATO, the UK was quite involved in this war. The UK and the US were two countries that became the political and military leadership in this struggle since its beginning, while reaching a peak in 1999. This situation involved talks in the British Parliament in the UK, especially the House of Lords where the decision-making aspect of parliamentary politics is achieved. The war was also a major concern for the parliament. On the one hand, it was important to resolve the situation in Kosovo without worsening it with other massacres. On the other hand, this situation required caution in dealing with the Serbian people. The destiny of Kosovo refugees was important to them. However, the future of the Serbian people in Kosovo had to be guaranteed. The most important thing was to obtain full autonomy for Kosovo, but also to achieve a bilateral cooperation from both countries. The House of Lords and the interest of some lords in this war made the British policy, as a whole, a lot more responsible for accomplishing what it had started since diplomacy regarding weapons and the military intervention used to manage the situation
\end{abstract}


of refugees in Kosovo had a huge impact in Europe. The British parliamentary sessions were very crucial in leading to an international level this whole historical phase for Kosovo.

Keywords: British parliament, Kosovo, Serbia, Albania

\section{In the context of British interests}

Involvement in turmoil for more than a decade led Kosovo to the peak of its suffering and conflict in 1999. The conflict between the Albanian population and the Serbian-Yugoslav political actors had begun in early 1998 and had an impact that was greater than the peninsula, including the continent as well as a political area larger than the continent itself. One should mention here some national institutions as was the example of the British Parliament.

The beginning of 1999 was not a favorable period for Albania. By 15 January 1999, there was a massacre which will be known as the Racak massacre. In this village, the Serbian army together with the paramilitaries massacred 45 people, including women and children (Ivo H. Daalder and Michael E. O’Hanlon, 2000). OSCE Head of Mission William Walker, who had visited the village, declared that it was a real horror scene. The British Parliament gave a strong response three days later. Drewienkiewicz, the British representative of OSCE, stated without hesitation that it was a civilian massacre because none of the casualties was wearing military uniforms. (Baroness Ramsay of Cartvale, 1999) They also knew that this was an order from above because the same situation had occurred in Bosnia and all the wars of the former Yugoslavia. (Lord Beloff, 1999)

However, the British Parliament would consider many later crimes as massacres based on their number and their psychological impact as well. A historical connotation was given to them when compared to similar massacres throughout human history. For many lords, these events were similar to the Armenian massacres of 1915 (The Earl of Shannon, 1999) because Serbs used to say that Albanians migrated to Kosovo. As a result, Serbs wanted to execute ethnic cleansing. Many Serbian deputies denied that the massacres had begun after the NATO's bombing because they were already informed that around 250,000 people had left Kosovo in 1998. (Mr. Crick Howell, 1999) They had noted an increase in the number of massacres and deportations from Kosovo in early bombing phases. (The Parliamentary Under-Secretary of State, Foreign and Commonwealth Office (Baroness Symons of Vernham Dean, 1999)

With the failure of the Rambouillet Meeting, this situation provided enough evidence to NATO and the British government that the last resort to stop the massacres was to initiate bombing. Shortly before the bombing, 
British Defense Minister George Robertson stated that there were about 6000 police officers and 20,000 military troops in Kosovo. (Ivo H. Daalder and Michael E. O’Hanlon, 2000) The aim of the attacks, according to him, was to lessen the degree of violence toward civilians in Kosovo. (Ivo H. Daalder and Michael E. O’Hanlon, 2000) Genocide and massacres of the population were not a mere internal issue of British Prime Minister Tony Blair. (Paul Latawski and Martin A. Smith, 2003) In the same way, throughout the first half of 1999, the British government stated that it was an act of genocide inKosovo from the Serbian part, and there was no other explanation for their actions. (Mick Hume, 2000)

The idea for a solution via a potential military attack was already discussed in the House of Commons since January 14, a day before the massacre in Racak. However, this was considered an impossible scenario since the troops that were present in Macedonia belonged to the mediation troops between Serbs and Kosovars and not to a third party. (The Parliamentary Under-Secretary of State, Foreign and Commonwealth Office (Baroness Symons of Vernham Dean), 1999) After reprisals on people and the failure of the Rambouillet talks, NATO started bombings on 24 March 1999. The British Minister of Defense declared in Parliament that the situation in Kosovo was like in the Middle Ages and not as on the verge of XXI century. It was not a matter between the people of Yugoslavia and them, but they wanted Slobodan Milosevic to withdraw from those actions. (The Minister of State, Ministry of Defense (Lord Gilbert), 1999) The British government also declared that it would stop after the withdrawal of the Serbian troops in Kosovo. (Baroness Symons of Vernham Dean, 1999) This statement, in a threatening style, expressed stability. The British government held this statement until early June when the Yugoslav government accepted the terms. The British and the American government were the first to propel submarines in the Adriatic Sea and bombed on the first night. (Bruce R. Nardulli et al., 1999).This war had such a strong impact on the British government that Lord Robertson in October 1999 in Institute for Strategic Studies in London stated that whenever you ask me whether this war was the right thing, I will be positive. (William M. Arkin, 2001)

However, the British parliament had MPs who did not see the war with the same optics as the British government. A part of the deputies who were against British involvement in the war tried to link the war with other experiences of their country's involvement in wars. Even before the bombing, many thought it could be like the Vietnam War, where one went for a little and stood for a long time. (Lord Burnham, 1999)The lack of military numbers was also a major problem along with internal problems that could follow. Earl Trenchard believed that the extent of the British army was at its maximum, and involvement in Kosovo would put a strain on the British 
people, especially if this engagement were for a long time. (Vikont Trenchard, 1999) These controversies are started becoming more prominent from time to time due to geostrategic interests, especially about national security. The British Minister of Defense Lord Gilbert declares at the end of May that we will stay in Kosovo only throughout the first phase of the return of Kosovars, then will gradually retire, leaving the room for countries, in geographical terms, closer to Kosovo. (The Minister of State, Ministry of Defense (Lord Gilbert), 1999)

Nevertheless, the British government, despite objections in parliament with some influence, was decisive in its involvement in the NATO bombing. Tony Blair stated that even alone would undertake these attacks to stand for the universal values of protecting the most vulnerable. (Charlotte Wagnsson, 2008) The insistence of Prime Minister Blair was also due to the support he had in parliament, where his party had about 179 chairs. Having a larger majority gave him confidence and support in the country, compared to other allies of NATO, which did not have this advantage. (Ivo H. Daalder and Michael E. O’Hanlon, 1999)

\section{The perception of the Kosovo war}

All the blame fell on Slobodan Milosevic since early 1999. According to the British parliament, he did not properly manage the situation in the country by causing massacres and large migrations of Kosovars. (The Secretary of State for Defense (Mr. George Robertson), 1999) They were also critical in the Paris talks between Serbs and Kosovars, where Albanians had only accepted self-determination for Kosovo within Yugoslavia, but the Serbian group did not agree. Milosevic was to blame since he had given the order. (Baroness Ramsay of Cartvale, 1999) He was considered as a person who had requested, through diplomatic, negotiations to gain time, since shortly after Paris talks, he ordered Serb troops to commit ethnic cleansing. (Baroness Jay of Paddington, 1999)This operation was known as "Patkova" (Horseshoe). (Benjamin S. Lambeth, 2001) It is seen as a retaliatory action against NATO, because, after every bombing by NATO till the end of April, there was a reprisal in Kosovo. (Lord Kennet, 1999) However, the British government with Baroness Simon said in the House of Commons that we do not aim to remove Milosevic from power; this right belongs to the Serbian people if they wish to keep or overthrow the government. (Baroness Symons of Vernham Dean, 1999) It was in the wake of statements made at the beginning of the bombing with the goal to diminish the military repression toward Kosovars. The British Parliament had also come to a conclusion that the operations had reached a peak to pure ethnic cleansing in Kosovo.

The impact of these bombings on the Serbian people in the context of an assessment of whether the bombing was appropriate or not was highly 
important to the British parliament. Since the early days of the bombing, many MPs were concerned if the bombings would have an impact on the Serbian people; if they would decrease or increase the support of the governance of Slobodan Milosevic. Since these bombings would affect civilians, they knew that civilians would not understand them as NATO groups did. After this action, many feared whether this country would tend to move more toward the East. (Lord Rodgers of Quarry Bank, 1999) Many old deputies knew that the Serbs were a proud people and would not easily be defeated. They knew that the Serbs in the previous wars had faced the armies many times greater than theirs. Nevertheless, the British Defense Ministry did not necessarily share this idea. Lord Gilbert stated that the three most important points were in their favor. First, generals noticed that the Serbian logistics, being destroyed, could not compare to the British one. Second, officers also believed that the chance to make a military career was almost impossible, and third, the soldiers manipulated that they would win, had begun to realize the contrary. (The Minister of State, Ministry of Defense (Lord Gilbert), 1999)After the bombing, Earl of Drogheda demanded to assume responsibility for potential Serbian causalities during the NATO bombing. (The Earl of Drogheda, 1999) The British government acknowledged that there had been civilian casualties in Serbia. Nevertheless, it was justified by simply being inadvertent, and this was a big difference compared to deliberate massacres of Milosevic in Kosovo. There was a lot of criticism in parliament concerning the bombing. It was considered a cause of encouragement for the Serbian government to undertake greater reprisals in Kosovo. It was not a very far-sighted policy of NATO. (The Independent International Commission on Kosovo, 2000)

Based on the propaganda that Slobodan was spreading in the country, several British MPs were also concerned about the support of some people to Milosevic. They stressed the need to make an anti-propaganda which would show people the truth. The people would see the true crimes and understand how they were being manipulated. However, the British government stated in parliament that our anti-propaganda consisted of two forms. Firstly, based on web pages in Serbian, and secondly, by throwing leaflets in Serbia indicating the massacres in Kosovo. (The Lord Privy Seal (Baroness Jay of Paddington), 1999) There was an increase of Serbian followers on the BBC website. The reactions were positive, and they were thankful for understanding the reality as it was. (Lord Newby, 1999) Protests had started again in Belgrade against Milosevic regime, and the British government considered them as a response to the information they were receiving.

The bombings began on 24 March 1999. However, starting from January the British MPs had urged the British government to intervene so that it stabilizes the situation. (Mr. Maples, 1999) It was confirmed by the 
Ministry of Defense in February when the Rambouillet talks had begun. Nevertheless, many other MPs were against this action. They knew that Serbia was not Iraq, and it was a nation which had fought for its position since 1914. (Lord Burnham, 1999) They also knew that such an action would require many weeks, and eventually would take a lot of lives. (The Lord Privy Seal (Baroness Jay of Paddington), 1999) By the end of April, it was announced that troops would only be for peacekeeping purposes. In fact, Wesley Clark had asked in early March for an Anglo -American troop intervention to stabilize the situation in the country. (William M. Arkin, 2001) However, after the NATO summit, which was held in Chicago in April 1999, the British Foreign Minister Robin Cook said that the best thing to do was to add land forces. (Benjamin S. Lambeth, 2001)

Among NATO members, there was a dilemma whether to intervene with land forces or not, and the most diligent members to intervene was the UK. (Charlotte Wagnsson, 2008) In the beginning, there were objections from Americans who were not very supportive of land intervention. The tension between the close allies was created, when Blair declared that we will intervene without American help. (John Norris, 2005) It was also reflected in Parliament in May when the supporters of intervention were prevailing. It might have happened because they were already tired of waiting for a quick solution based on bombing. The Minister of Defense declared that they would enter the country with an army until winter, and some supporters justified this approach that if Milosevic entered Kosovo with the Army to murder, we do have the right to enter the country to protect the civilian population. (Lord Mayhew of Twysden, 1999) However, as events unfolded during early June, fortunately, there was no need to intervene with land forces in Kosovo as well as in Serbia.

There were different viewpoints towards Albanians or Albanian armed groups in the country as was the case of the Kosovo Liberation Army (KLA). To reduce the consequences of the Serbian army in the country, they did not require involving KLA in combat, because it was accused of receiving weapons from the Albanian border in early January, and for this situation, the best thing to do was to monitor this part of the border. (Lord Hylton, 1999) The leaders of Anglo-American politics did not favorably see KLA' provocations to the Serbian army. To Clinton, it posed a problem. While, the British Prime Minister Tony Blair believed this provocation could have its negative impact on Kosovo citizens who believed that the consequences could fall on civilians. (Ivo $\mathrm{H}$. Daalder and Michael E. O’Hanlon, 2001) There are even some of those MPs who said that guns were bought with profits from drugs dealing and prostitution. (Lord Redesdale, 1999) The same standpoint concerning Kosovo had the representative of president Jelcin, Victor Chernomyrdin, who could collect amounts of money 
reaching up to one billion dollars. (ShaqirVukaj, 2007) The Minister of Defense George Robertson said that this army was terrorizing the civilian population for revenge. (The Secretary of State for Defense (Mr. George Robertson), 1999) By the end of May, the British government was not satisfied with the KLA, which had not yet reduced the number of attacks. (The Minister of State, Ministry of Defense (Lord Gilbert), 1999) In early June, there were also talks for its demilitarization, and since the beginning of March, the KLA was required to leave the military combat. The army had to be dispersed by the end of the bombing. The number of soldiers of this organization amounted up to 18000 people. From this number, an amount of 3000 people available at all time during the wars. (James Pettifer, 2013) Even though commanders of the KLA had always publicly declared that they had never treated civilians badly, (Hajredin Muja, 2012) they were still criticized for their deeds and were asked to stop their activity. The purpose of this criticism was on the ground that NATO forces being the only force to fight in this war, and there was an increasing demand to impede the land fighting. It was also believed that the withdrawal of this army as a combat party could somehow reduce the counter-response of Serbian military fighting.

There was a special standpoint toward Albania. Being well connected regarding the ethnic and geostrategic position of the two countries, they knew this war would have a double impact on the territory of Kosovo as well as Albania. One of the main problems discussed in this case was the weapons' trade. Officials of the British Foreign Ministry, as well as other deputies, claimed that they had evidence that some of the munitions taken by the KLA came from Albania. (The Parliamentary Under-Secretary of State, Foreign and Commonwealth Office (Baroness Symons of Vernham Dean), 1999) These people, being experts in political conditions in which Albania was and considering the same national feelings among Albanians and people of Kosovo, knew that it was impossible to ban it to the Albanian state. For them, the only solution was to close the Albanian- Yugoslavian border (i.e. the part with Kosovo). British soldiers would be deployed in that part of the border. This action would curb the flow of weapons. (Baroness Williams of Crosby, 1999) It was particularly demanded especially after the Racak massacre since the counter response could be greater from Kosovo. Therefore, this conduct would ban potential human massacre. The British Parliament also requested Albania to hold off military and political actions since the end of March 1999, especially after the start of the bombing. They feared the domino effect that this war could have in the Balkans. (Lord Judd, 1999) Because of the location of Kosovo between two countries with Albanian populations, as Albania and Macedonia are, war could expand in 
these areas as well. Albania was especially in chaos by internal political factors during that period. (Baroness Williams of Crosby, 1999)

The aspect of emigration of Kosovars, considering the human and health aid, was delegated to Albania. Albania had granted a humanitarian aid beyond its capacity considering all the problems it was facing as assessed by the British Parliament. The Parliament was also considering if Albania was properly assisted during this war. (The Earl of Sandwich, 1999) The future of Kosovo on an international arena was a crucial problem discussed in different stages during the war. The destiny of Kosovo, the establishment of a political status in Kosovo and the two alternatives in case the country would remain under the political integrity of Yugoslavia with autonomy or become independent. The autonomy was undeniable for the British government and deputies. However, the autonomy was nonnegotiable to the Serbian party. (Baroness Ramsay of Cartvale, 1999) There were deputies in the parliament who knew Serbian viewpoints and politics, and they knew what Yugoslavia had done for half a century. They also knew that Serbia had never accepted this despite the huge attempts of Tito to establish a federal republic under the Yugoslavian authority. (Baroness Ryder of Warsaw, 1999) The idea of a broad autonomy continued until the end of May even when the standpoint of Serbian party was not changing. The people were also asked to return home safe. However, the possibility of Kosovo to become an independent state was negotiated. (Lord Weatherill, 1999)

\section{Human reintegration and ethnic balance in Kosovo}

This form of declaration was done intentionally to pacify the Serbian reaction. Therefore, the idea of autonomy was still mentioned in order not to diminish the territorial integrity of Serbia and, at the same time, not to jeopardize the life of civilians from Yugoslavia, in case there were early declarations of independence. It would also stop emotionally- driven actions of the people of Kosovo after this declaration. Nevertheless, Serbians would be blamed for not accepting a multi-ethnic Kosovo. (Mr. Cook, 1999) This declaration given by Mr. Cook denoted that the ethnic cleansing undertaken by the Serbian army was seen as a reaction showing their concern if recognizing this nation as comprised of other people other than Serbians. Nevertheless, Western diplomats, including the British ones had left some room for discussions for an independent Kosovo in the future. It was firstly agreed upon a period of 3 months to allow KFOR soldiers in Kosovo with the number reaching over 4000, (Mr. Cook, 1999) and later on having a discussion on a referendum. Apparently, it was believed that many aggressive elements would be more accommodating from both sides during this stage and Serbs could have the chance to change their views after Milosevic left, as they were also being asked to from time to time. It would 
lead to independence accompanied by a peaceful acceptance, as an existential precondition for both political entities- Serbia and Kosovo. It was not the right moment to openly discuss the independence of Kosovo rather than the lack of willingness to proclaim it as an independent country. A declaration of this kind would act as an incentive rather than a positive reaction to the situation since the war was at its peak. The emergence of a human sentiment was very important in the course of the talks of the British Parliament concerning the refugees. Its biggest impact was the devastation of the country and the emergence of refugees during the ethnic cleansing of the war. The concern for Kosovo refugees in this parliament was multidimensional.

Firstly, the British people had collected about 10 million pounds as soon as war broke. The money was collected from the propaganda of many MPs in cooperation with NGOs. (Baroness Jay of Paddington, 1999) They involved British military aircraft being present in Macedonia because they were concerned about the safety of human beings. The aircraft monitored the people and kept them safe from the Serbian army attacks. (Lord Kenet, 1999) They sought to go beyond just military action so that they could safeguard refugees even though NATO had not declared its troop involvement in Kosovo. In hearings on this issue, it was occasionally requested that all the food wasted in the country to be used in order to help the refugees. (Baroness Rawlings, 1999) The British camps in Macedonia had collaborated with the Bulgarians to stock fast and good quality food supplies. Bulgaria, a country close to Macedonia asked by the British to create refugee camps. (Baroness Rawlings, 1999) Many young men of Kosovo tried to pass the border and move to the UK. They were imprisoned because they were not equipped with the right travel documents. The British parliament did not consider it as the right approach. They believed that these actions were done for specific reasons, and the best approach was to free them and give the status of an asylum seeker. (Baroness Williams of Crosby, 1999)

In order to facilitate the procedures to enter Europe, there was a demand to issue the Nansen passport. (Baroness Park of Monmouth, 1999) Since Kosovo people had been travelling with Serbian travel documents, Serbia had restricted their travelling outside the country. In this way, Nansen passport was proposed in order to avoid the chaos that could be created when it came to the legal aspect of their emigration. This passport was first issued by the League of Nations during the 20s of the 20th century. (Nansen passport, 2015) The British government tried to be cautious by not entering the Kosovo's land with the army. Such a positioning would lead to a Serbian reaction, and civilians would be the one to pay for it with casualties. They even declared that this would be done in cooperation with the USA to bring some relief to the people of Kosovo. 
The special treatment of refugees was another important concern. There was a proposal to bring women and children to EU countries since April (including the UK), until the end of the war. (Lord Evans of Parkside, 1999) However, used to the idea of the constant threat of invasion for decades and centuries, the concept of relating their destiny to that of their land was deeply embedded in refugees. They refused to go to areas far away from the border of Kosovo, even if they were offered better conditions by countries overseas. They wanted to be close to Kosovo so they could easily go back to the war. (Baroness Amos, 1999) The number of Kosovo citizens who had emigrated was high in early May as refugees in camps built by NATO countries and NGOs was over 400,000 people in Albania and around 200000 people in Macedonia. In all these camps there was assistance in personnel and logistics supported by the British. Despite this great support, MPs in the parliament sought to assist refugees further. Many MPs, recalling previous experiences in times of political crisis that had created an influx of emigrants, asked the help of universities to give their support via their study programs; as they had previously done with the refugee crisis from Czechoslovakia. (Lord Quirk, 1999)

The British government also facilitated the connection of different immigrants who were in the UK with the rest of the refugees. (Baroness Amos, 1999) This action would enable some spiritual relief to ease the pain of war. The spiritual relief for the refugees was done hand in hand with the military operations by NATO. It had a direct impact on the population of Kosovo, as was the impact of the bombing later on. However, all political or military steps were firstly considered based on the importance of ethnic relationships. One of the states that carefully considered the balance between the two groups and the Serbians was Great Britain. This approach was also clearly expressed in the British Parliament. They knew that different Serbian groups would start ethnic hatred with other groups once Milosevic came into power, and this war itself was a result of this approach followed since the 1980s. (Lord McNair, 1999)

But hatred was not manifested only by Serbians. It was equivalent in both ethnic groups- Serbs and Albanians. The latter experiencing a disappointment lasting for decades in Yugoslavia had accumulated a great hatred and pressure against the Serbian people. In most cases, the hatred was due to several reasons and these reasons were accompanied by facts. They knew that both parts would hate each other; even after the war. (Lord Crickhowell, 1999) Since the Rambouillet talks, they had realized that neither side would want to establish tolerant diplomatic actions. However, the Serbs did not want to give a solution, while the Albanians did not tolerate any element. (John Norris, 2005) 
NGOs, as well as KFOR troop, were going to Kosovo to prevent any ethnic confrontation since both sides could fall into conflict. The British government was aware that the hatred was part of both sides. (Lord Evans of Watford, 1999)

They already feared a revenge coming from Kosovo people who were burdened by the psychoses of tragic memories that had experienced, and they could create turmoil with the Serbian population in Kosovo after being freed from Serbian constraints as well as under the protection of the international presence. Fortunately, the population was peaceful after the war, except sporadic cases.

The MPs, who were responsible for humanitarian intervention, were trying to maintain the balance in the belief of keeping every civilian safe. By the beginning of May, the importance of the Serbs' safety in both Serbia and Kosovo began to gain interest. This concern was not only mentioned in the British Parliament, but also in the European Youth Parliament. (Lord Ponson by of Shulbrede, 1999) The House of Lords also required that all the people affected by this war had to be helped, which meant the Serbian civilian population wherever it was. Whereas in early June, when it seemed that everything was being successfully completed, and this success would be on the side of Kosovars, the safety of everything related to Serbian culture and the Serbian people in Kosovo became a great concern.

It was required to create a commission to protect the Serbian values in Kosovo. A Serbian person had to be in the commission's composition to provide information about these areas. (Lord Gilbert, 1999) The British, with the will to bring back harmony and encourage the recovery of Kosovo as a whole, started rebuilding homes as a sign of charity in new Serbian towns in Kosovo after the war and gave them historical names as it was the case of Obilic. (Tim Judah, 2008)

This important stage for Kosovo was discussed by the British parliamentary politics. In many cases, the parliament had an impact on British national policy as well as internationally. Many events that had to do with the war in Kosovo, for many people the political involvement of government and high-esteemed British personalities or those of Western policies is taken into consideration. However, one should acknowledge the contribution and the persistence of the two chambers of the British parliament. This state with an eight- hundred- year- old parliament recognized its realm in the policy-making of that moment. Their activity more than anything else is seen as a balancing power toward governmental actions. On a larger scale as corrective toward military policy. Whereas other cases were a good example of British humanitarian values, particularly in safeguarding human and political balances among groups. This parliament influenced greatly on the achievement of positive outcomes. 


\section{References:}

Ivo H. Daalder and Michael E. O’Hanlon, Winning Ugly NATO’s War To Save Kosovo.

(Washington, D.C.: Brookings Institution, 2000), 63.

Baroness Ramsay of Cartvale, Kosovo: 18 January 1999 at http://hansard.millbanksystems.

Com/lords/1999/Jan/18/kosovo\#S5LV0596P0_19990118_HOL_191

Lord Beloff, Kosovo: 18 January 1999 at

http:/hansard.millbanksystems.com/lords/1999/

Jan/18/kosovo\#S5LV0596P0_19990118_HOL_191

The Earl of Shannon, Armenian Massacre 1915: 14 April 1999 at http://hansard.millbank

systems.com/lords/1999/apr/14/armenian-

massacr1915\#S5LV0599P0_19990414_HOL 147

Mr. Crickhowell, Kosovo: 06 May 1999 at http://hansard.millbanksystems.com/lords/1999

/may/06/kosovo\#S5LV0600P0_19990506_HOL_91

The Parliamentary Under-Secretary of State, Foreign and Commonwealth Office (Baroness Symons of Vernham Dean), Yugoslavia: NATO Bombing and Geneva Conventions: 18 May

1999 at http://hansard.millbanksystems.com/lords/1999/may/18/yugoslavianato-bombing-and-geneva\#S5LV0601P0_19990518_HOL_60

Ivo H. Daalder and Michael E. O’Hanlon, Winning Ugly, 103.

Ivo H. Daalder and Michael E. O’Hanlon, Winning Ugly, 116.

Paul Latawski and Martin A. Smith.The Kosovo crisis and the evolution of post - Cold War

European security, (Manchester: Manchester University Press, 2003), 25.

Mick Hume, "Nazifying the Serbs, from Bosnia to Kosovo" in Degraded Capability: The

Media and the Kosovo Crisis, ed. Philip Hammond and Edward S. Herman (London: Pluto Press, 2000), 73.

The Parliamentary Under-Secretary of State, Foreign and Commonwealth Office (Baroness Symons of Vernham Dean), Kosovo: UK Monitors: 14 January $1999 \quad$ at http://hansard.millba nksystems.com/lords/1999/jan/14/kosovo-uk-

monitors\#S5LV0596P0_19990114_HOL_21

The Minister of State, Ministry of Defence (Lord Gilbert), Kosovo: 24 March 1999 http://hansard.millbanksystems.com/commons/1999/mar/24/kosovo\#S6CV0 328P0_19990324_HOC_502 
Baroness Symons of Vernham Dean, President Milosevic: 21 April 1999 at http://hansard. millbanksystems.com/lords/1999/apr/21/presidentmilosevic\#S5LV0599P0_19990421_HOL_61

Bruce R. Nardulli et al., Disjointed War Military Operations in Kosovo, 1999, (Pittsburg: RAND, 2002), 24.

William M. Arkin, “Operation Allied Force: "The Most Precise Application of Air Power in History"”' in War Over Kosovo Politics and Strategy in a Global Age, ed. Andrew J. Bacevich and Eliot A. Cohen (New York: Columbia University Press, 2001), 26.

Lord Burnham, Kosovo: 11 February 1999 at http://hansard.millbanksystems.com/

commons/1999/feb/11/kosovo\#S6CV0325P0_19990211_HOC_490

Vikont Trenchard, Armed Forces: 24 February 1999, at http://hansard.millbanksystems .com/lords/1999/feb/24/armedforces\#S5LV0597P0_19990224_HOL_217

The Minister of State, Ministry of Defence (Lord Gilbert), Kosovo: 26 May 1999 at

http://

hansard.millbanksystems.com/written_answers/1999/may/26/kosovo\#S6CV 0332P0_19990526_CWA_32

Charlotte Wagnsson, Security in a greater Europe The possibility of a panEuropean approach, (Manchester: Manchester University Press, 2008), 27.

Ivo H. Daalder and Michael E. O’Hanlon, Winning Ugly, 132.

The Secretary of State for Defence (Mr. George Robertson), Kosovo: 25 January 1999

http://hansard.millbanksystems.com/commons/1999/jan/25/kosovo\#S6CV03 24P0_19990125_HOC_52

Baroness Ramsay of Cartvale, Kosovo: OSCE Verification Mission: 23 March 1999

at http://hansard.millbanksystems.com/lords/1999/mar/23/kosovo-osceverification-missi on\#S5LV0598P0_19990323_HOL_16

Baroness Jay of Paddington, Berlin European Council, and Kosovo: 29 March 1999 at Htt: //hansard.millbanksystems.com/lords/1999/mar/29/berlin-european-counciland-kosovo\#S5 LV0599P0_19990329_HOL_113

Benjamin S. Lambeth, NATO's Air War for Kosovo A Strategic and Operational Assessment, (Pittsburg: RAND, 2001), 9.

Lord Kennet, Kosovo Refugees: Humanitarian Assistance: 31 March 1999 at http://hansard .millbanksystems.com/written_answers/1999/mar/31/kosovorefugee-numbers\#S5LV0599P0_19990331_LWA_69

Baroness Symons of Vernham Dean, President Milosevic: 21 April 1999 at http:/hansard. millbanksystems.com/lords/1999/apr/21/presidentmilosevic\#S5LV0599P0_19990421_H OL_61 
Lord Rodgers of Quarry Bank, Kosovo: 13 April 1999 at http://hansard.millbanksystems .com/commons/1999/apr/13/kosovo\#S6CV0329P0_19990413_HOC_127 The Minister of State, Ministry of Defence (Lord Gilbert), Kosovo: 06 May 1999 at HTTP:// hansard.millbanksystems.com/lords/1999/may/06/kosovo\#S5LV0600P0_19 990506_HOL_91

The Earl of Drogheda, Former Yugoslavia: NATO Military Activity: 08 June 1999 at HTTP: //hansard.millbanksystems.com/lords/1999/jun/08/formeryugoslavia-nato-military-activity \#S5LV0601P0_19990608_HOL_24

The Independent International Commission on Kosovo, The Kosovo Report Contact International Response Lessons Learned, (Oxford: Oxford University Press, 2000), 89.

The Lord Privy Seal (Baroness Jay of Paddington), Kosovo: 13 April 1999, at http://hansar d.millbanksystems.com/commons/1999/apr/13/kosovo\#S6CV0329P0_19990 413_HOC_12

Lord Newby, Public Service Broadcasting: 05 May 1999, at http://hansard.millbank systems.com/lords/1999/may/05/public-servicebroadcasting\#S5LV0600P0_19990505_HOL_170

Mr. Maples, Kosovo: 25 January 1999, at http://hansard.millbanksystems.com/commons/ 1999/jan/25/kosovo\#S6CV0324P0_19990125_HOC_52

Lord Burnham, Kosovo: $24 \quad$ March 1999 at http://hansard.millbanksystems.com/commons/ 1999/mar/24/kosovo\#S6CV0328P0_19990324_HOC_502 The Lord Privy Seal (Baroness Jay of Paddington), Kosovo: 13 April 1999, at http:/hansa rd.millbanksystems.com/commons/1999/apr/13/kosovo\#S6CV0329P0_1999 0413_HOC_127

William M. Arkin, “Operation Allied”, 3-4.

Benjamin S. Lambeth, NATO’s Air, 46.

Charlotte Wagnsson, Security, 25.

John Norris, Collision Course NATO, Russia, and Kosovo, (London: British Library Cataloguing, 2005), 29.

Lord Mayhew of Twysden, Kosovo: 06 May 1999 at http:/hansard.millbanksystems.com/ lords/1999/may/06/kosovo\#S5LV0600P0_19990506_HOL_91

Lord Hylton, Kosovo: 18 January 1999, at http:/hansard.millbanksystems.com/lords/1999/ jan/18/kosovo\#S5LV0596P0_19990118_HOL_191

Ivo H. Daalder and Michael E. O’Hanlon, Winning Ugly, 73. 
Lord Redesdale, Arms Trade: 20 January 1999 at http://hansard.millbanksystems.com/lords /1999/jan/20/armstrade\#S5LV0596P0_19990120_HOL_202

Shaqir Vukaj, Rusia dhe Kosova: Shënime të një diplomati, (Tiranë: Enrico Cuccia, 2007), 399.

The Secretary of State for Defence (Mr. George Robertson), Kosovo: 25 January 1999 http://hansard.millbanksystems.com/commons/1999/jan/25/kosovo\#S6CV03 24P0_19990125_HOC_52

The Minister of State, Ministry of Defence (Lord Gilbert), Kosovo: 26 May 1999 at

HTTP:// hansard.millbanksystems.com/written_answers/1999/may/26/kosovo\#S6CV 0332P0_19990526_CWA_320

James Pettifer, Ushtria Çlirimtare e Kosovës, nga një luftë e fshehtë në një kryengritje të Ballkanit 1948 - 2001, Përkth. Afërdita Cesula, (Tiranë: Unufri 2013), 254.

Hajredin Muja, Lufta e Kosovws nw shtypin amerikan: 28 Shkurt 1998 - 10 qershor 1999, (Shkup: Logos - A, 2012), 247.

The Parliamentary Under-Secretary of State, Foreign and Commonwealth Office (Baroness Symons of Vernham Dean), Kosovo: UK Monitors: 14 January 1999, at http:/hansard. millbanksystems.com/lords/1999 /jan/14/ kosovo-uk-monitors\#S5LV0596P0_19990114_HOL_21

Baroness Williams of Crosby, Kosovo: 18 January 1999 at http:/hansard.millbanksystems .com/lords/ 1999/jan/18/kosovo\#S5LV0596P0_19990118_HOL_191

Lord Judd, Kosovo: 24 March 1999 at http://hansard.millbanksystems. com/commons /1999/mar/ 24/kosovo\#S6CV0328P0_19990324_HOC_502

Baroness Williams of Crosby, Kosovo Refugees: Humanitarian Assistance: 31 March 1999 at http://hansard.millbanksystems.com/written_answers/1999/mar/31/kosovorefugee-num bers\#S5LV0599P0_19990331_LWA_69

The Earl of Sandwich, Balkan Refugee Camps: Support for NGOs: 13 May 1999 at HTTP:// Hansard. millbanksystems.com/lords/1999/may/13/balkanrefugee-camps-support-for-ngos \#S5LV0600P0_19990513_HOL_53

Baroness Ramsay of Cartvale, Kosovo: 18 January 1999 at http://hansard. millbanksystems.com/lords/1999/

jan/18/kosovo\#S5LV0596P0_19990118_HOL_191

Baroness Ryder of Warsaw, Ibid

Weatherill, Tibet: 10 May 1999 at http://hansard.millbanksystems.com/lords /1999/may/10/tibet\#S5 LV0600P0_19990510_HOL_230 
Mr. Cook, $\quad$ Balkans: $18 \quad$ May 1999 at http://hansard.millbanksystems.com/commons/1999 /may/18/balkans\# S6CV0331P0_19990518_HOC_53

Mr. Cook, Ibid

Baroness Jay of Paddington, Berlin European Council, and Kosovo: 29 March 1999

http://hansard.millbanksystems.com/lords/1999/mar/29/berlin-europeancouncil-and-kosovo \#S5LV0599P0_19990329_HOL_113

Lord Kennet, Ibid.

Baroness Rawlings, Kosovo Refugees: Humanitarian Assistance: 31 March 1999 at HTTP:/ Hansard.Milbank systems.com/written_answers/1999/mar/31/kosovo-refugee-numbers\#S5

LV0599P0_19990331_LWA_69

Baroness Rawlings, Ibid.

Baroness Williams of Crosby, Ibid.

Baroness Park of Monmouth, Ibid.

Nansen passport, at https://en.wikipedia.org/wiki/Nansen_passport

Lord Evans of Parkside, Kosovo: Humanitarian Assistance: 27 April 1999 at HTTP:// Hansard.Millbank systems.com/lords/1999/apr/27/kosovohumanitarian-assistance\#S5LV0 600P0_19990427_HOL_23

Baroness Amos, Ibid.

Lord Quirk, The Balkans: Economic and Political Development: 12 May 1999 at http://hansard.millbank systems.com/lords/1999/may/12/the-balkanseconomic-and-political \#S5LV0600P0_19990512_HOL_13

Baroness Amos, Balkan Refugee Camps: Support for 13 May 1999 at http://hansard. Millbank systems. com/lords/1999/may/13/balkan-refugeecamps-support-for-ngos\#S5LV0 600P0_19990513_HOL_53

Lord McNair, Kosovo: 24 March 1999 at http://hansard.millbanksystems.com/commons /1999/mar/24/ kosovo\#S6CV0328P0_19990324_HOC_502

Lord Crickhowell, Kosovo: 06 May 1999 at http://hansard.millbanksystems.com/lords /1999/may/

06/kosovo\#S5LV0600P0_19990506_HOL_91

John Norris, Collision course, xxi.

Lord Evans of Watford, India and Pakistan: 20 April 1999 at http://hansard.millbank systems.com/lords/1999/ apr/20/india-andpakistan\#S5LV0599P0_19990420_HOL_280

Lord Ponson by of Shulbrede, Council of Europe: 05 May 1999 at http://hansard.millbank systems.com/lords/1999/may/04/business-of-thehouse-debates-6th-may\#S5LV0600P0_19990504_HOL_65 
Lord Gilbert, Kosovo:10 June 1999 at http://hansard.millbanksystems.com/lords/1999/jun /10/kosovo\#S5LV0601P0_19990610_HOL_77

Tim Judah, KOSOVO What Everyone Needs to Know, (Oxford: Oxford University Press, 2008), 45. 